\title{
Corruption and Public Service in an Extended Solowian Growth Model with Endogenous Labor Supply
}

\author{
Wei-bin ZHANG' 1 (B)
}

\section{ABSTRACT}

This study examines the impact of bureaucratic corruption on economic growth of a small open economy. The economy is composed of two types of households (the workers and the officials) and two sectors (the industrial sector and public sector). Corruption may occur in different parts of the economy. We built a model for analyzing the role of corruption on economic growth, income and wealth distribution between the officials and workers. The model takes account of corruption in the capital market, the labor market, and production sector. It describes dynamic interactions of growth, corruption with endogenous tax rate and different exogenous corruption rates. We simulate motion of the dynamic system and demonstrate how an increase of corruption in the production sector, in the labor market, and other parameters affect the transitory process and long-run state of economic growth.

Keywords: Economic growth, corruption rate on wealth, corruption rate on wage income, corruption rate on output, small-open economy, endogenous labor supply

JEL Classification: O41, D3, E2

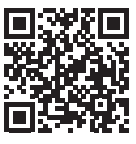

DOI: $10.26650 / J E P R 768781$

'Prof., Ritusmeikan Asia Pacific University, Tokyo, Japan

ORCID: W.Z. 0000-0002-3012-304X

\section{Corresponding author/Sorumlu yazar:} Wei-bin ZHANG,

Ritusmeikan Asia Pacific University, Tokyo, Japan

E-mail/E-posta:wbz1@apu.ac.jp

Submitted/Başvuru: 09.04.2020 Revision Requested/Revizyon Talebi: 28.05.2020

Last Revision Received/Son Revizyon: 10.06.2020

Accepted/Kabul: 22.06 .2020

Citation/Atıf: Zhang, W. (2020). Corruption and public service in an extended solowian growth model with endogenous labor supply. Iktisat Politikası Araştırmaları Dergisi - Journal of Economic Policy Researches, 7(2), 1-20. https://doi.org/10.26650/JEPR768781 


\section{Introduction}

Corruption is a significant factor in economic growth. Corruption penetrates almost any sectors of socioeconomic systems. Nevertheless, it is not easy to follow dynamic processes of corruption and its effects on economic development. It is generally agreed that corruption may either decrease or increase economic growth, depending on how corruption interacts with the rest of the system. Another important aspect of corruption which is seldom theoretically studied is how the wealth and income accumulated due to corruption are used. Intuitively, in a neoclassical growth economy, if corruption has little negative impact on productivities and the corrupt wealth are saved and put back to the economy, the national saving rate may be increased. A rise in the propensity to save enhances the national growth rate, as the standard neoclassical growth theory predicts. This study examines the impact of bureaucratic corruption on economic growth by taking account of various corrupt effects on different aspects of economic systems. To simplify the modelling, this study deals with an economy with two types of households (the workers and the officials) and two sectors (the industrial sector and public sector). This study takes account of corruption in the capital market, the labor market, and production sector. The model describes dynamic interactions of growth, corruption with endogenous tax rate and different exogenous corruption rates. We are concerned with the role of corruption on economic growth and income and wealth distribution between the officials and workers.

Becker (1968) provides an early formal economic explanation on economic behavior with corruption. There are a few theoretical research articles about interactions between corruption and economic growth (Rose-Ackerman, 1999; Shi and Temzelides, 2004; Dzhumashev, 2014; D’Agostino, et. al. 2016). There is vast literature of empirical studies on interactions between corruption and economic growth (e.g., Mauro, 1995, 1998; Ehrlich and Lui, 1999; Del Monte and Papagni, 2001; Rivera-Batiz, 2001; Glaeser and Saks, 2006; Swaleheen and Stansel, 2007; Teles, 2007; Acemoglu and Verdier, 1998; Gyimah-Brempong, 2002; Chea, 2015). These theoretical and empirical studies investigate different aspects of corruption. Nevertheless, there is no converged conclusion on the impact of corruption on growth. One finds opposite answers, as summarized by Chea (2015: 187): "From the theoretical background and empirical evidence from various studies spread in various countries in the world using different methods over the years, there are mostly negative findings of economic growth. Nevertheless, there are also positive findings found on the effects of corruption on economic growth." In the early literature, the positive effect is pointed out, for instance, by Leff (1964) and Huntington (1968). According to Huntington, "efficient corruption" may occur in the form of bribery as firms can get works completed in a political economic environment plagued by bureaucratic complexity. Corruption smooths operations so that the efficiency of the whole systems are enhanced (Mo, 2001). On the other 
hand, Myrdal (1968) points out the negative impact of corruption. Corrupt officials may delay permissions of projects to obtain bribes. Dzhumashev (2014: 203) reviews: "the existing literature lacks a more general approach for interpreting the role of governance, the size of government, and the level of development in the relationship between corruption and growth." This study is to contribute to the literature of the relationship between corruption and growth in a neoclassical growth framework.

This study proposes a dynamic general equilibrium framework. Following Barro (1990) and Turnovsky $(2000,2004)$, we deal with the impact of officials' behavior on productivity of the production sector. The officials supply public goods/service and public goods affect the productivity of the production sector. Moreover, how intensively officials work is dependent on their incomes. Workers' time distribution is also endogenous in our approach. The production sector is taxed to support the public sector. This study extends the growth model with public goods by Zhang (2010). It generalizes Zhang's growth model by classifying the population into the workers and the officials. This study is influenced by Lin and Zhang (2009). According to Lin and Zhang (2009: 69), "Most prior theoretical studies have been devoted to understanding the micro-foundation of the determination of corruption and the implications for efficiency. Relatively few attempts have been made to analyze corruption with a dynamic general equilibrium framework." Different from the traditional two-periodic growth model as applied by Lin and Zhang, we apply Zhang's concepts of current and disposable incomes and utility function (Zhang, 2009, 2020). This study is concerned with a small open economy. There are many studies on economic growth of open economies (e.g., Obstfeld and Rogoff, 1996; Lane, 2001; Kollmann, 2001, 2002; Benigno and Benigno, 2003; Galí and Monacelli, 2005; Uya, et al. 2013; and Ilzetzki, et al. 2013). We follow the neoclassical growth tradition of modelling small open economies. The rest of the paper is organized as follows. Section 2 develops the basic model of wealth accumulation and corruption within the two-sector, two-group neoclassical growth framework. Section 3 examines dynamic properties of the model. Section 4 carries out comparative dynamic analysis. Section 5 concludes the study.

\section{The Basic Model}

The economy under consideration is composed of one industrial sector and one public sector. The population is classified into the official and the worker. Each group is homogenous, and the population of each group is fixed. The economy is open and there is free trade between the economy and global markets. There is a single tradable good in the global market. The industrial good's price is unity. Capital depreciates at a fixed rate $\delta_{k}$, Most aspects of the industrial sector are similar to the standard one-sector neoclassical growth model (Burmeister and Dobell, 1970; Barro and Sala-i-Martin, 1995). Workers are 
fully employed by the industrial sector and officials are fully employed by the public sector. Households own assets of the economy. The households use their disposable incomes for consumption and saving. The rate of interest $r^{*}$ is fixed in international markets. The industrial sector uses labor and capital inputs to produce goods. Exchanges take place in perfectly competitive markets. Factor markets work well, and factors are fully utilized at every moment. Saving is undertaken only by households. We use subscripts $j=1$ and $j=2$ to stand for workers and officials respectively. Let $\bar{N}_{j}$ represent the fixed population of group $j$. The time is divided between leisure and work. We use $T_{j}(\mathrm{t})$ to stand for the work time of household $j$. Let $N_{j}(\mathrm{t})$ stand for group labor force at time $t$. We have $N_{j}(\mathrm{t})$ as follows:

$$
N_{j}(t)=h_{j} \bar{N}_{j} T_{j}(t)
$$

where $h_{j}$ is the fixed level of human capital of the representative household in group $j$.

\section{The Industrial Sector}

The impact of public goods and services is modelled in the literature of economic growth with public goods supply (e.g., Glomm and Ravikumar, 1997; Palivos, et al. 2003; Hu, et al. 2008; Kamiguchi and Tamai, 2011). We take the following standard production function of industrial sector with public goods:

$$
F(t)=A G^{\theta}(t) K^{\alpha_{i}}(t) N_{1}^{\beta_{i}}(t), \alpha_{i}+\beta_{i}=1, A, \theta, \alpha_{i}, \beta_{i}>0,
$$

where $A, \theta, \alpha_{i}$ and $\beta_{i}$ are parameters. According to Dzhumashev (2014:202): "When the public and private sectors interact, bureaucrats may abuse their public position for private gains by accepting bribes or even actively extorting them. This behavior is defined as an act of bureaucratic corruption." In the model of growth and corruption, Chen and Guo (2014) omit the possible impact of public goods on productivity. The omission may result in misleading conclusions on the impact of corruption as the officials supply public services and public services may obviously affect the productivity of the private sector. De Vaal and Ebben (2011) take account of possible effects of public goods $G(\mathrm{t})$ on productivity. We follow this approach. We use $\varphi$ to stand for the fixed corruption rate on the output level of the industrial sector. The tax rate on output $\tau(\mathrm{t})$ is endogenously determined by the government budget. Let $\bar{\varphi}(\mathrm{t}) \equiv 1-\varphi-\tau(\mathrm{t})$. Here, we neglect any effect of corruption on firms' capital and labor force. The profit of the industrial sector is:

$$
\bar{\varphi}(t) F(t)-\left(r^{*}+\delta_{k}\right) K(t)-w_{1}(t) N_{1}(t)
$$

where $w_{1}(\mathrm{t})$ is the worker's wage rate per unit of time. The marginal conditions are:

$$
r_{0}=\frac{\alpha_{i} \bar{\varphi}(t) F(t)}{K(t)}, w_{1}(t)=\frac{\beta_{i} \bar{\varphi}(t) F(t)}{N_{1}(t)}
$$


where $r_{0} \equiv r^{*}+\delta_{k}$. Here, we don't take account of possible corruption on taxation as in the literature (e.g., Baier and Glomm, 2001; Aghion, et. al., 2016).

\section{Workers' Disposable Income and Budget Constraint}

This study applies Zhang's utility and concepts of current and disposable income in modelling the behaviour of the household (Zhang, 1993, 2009). We use $\bar{k}_{1}(t)$ to represent the wealth owned by the representative work. When there is no corruption of the worker, we have the worker's current income as follow $r^{*} \bar{k}_{1}(t)+w_{1}(t) T_{1}(t)$. The total value of wealth that the representative worker can sell to purchase goods and to save is $\bar{k}_{1}(t)$. We assume that selling and buying wealth can be conducted instantaneously without any transaction cost. We have the worker's disposable income as follows:

$$
\bar{k}_{1}(t)+r^{*} \bar{k}_{1}(t)+h_{1} w_{1}(t) T_{1}(t) .
$$

We consider that bribes and other corruption activities take place in the labor and capital markets. We assume that the corruption rates on wealth and wage rate are respectively denoted by $\varphi_{k}$ and $\varphi_{w}$ After paying the corruption fee to the officials, the representative household's disposable income $\hat{y}_{1}$ is:

$$
\hat{y}_{1}(t) \equiv r_{1} \bar{\varphi}_{k} \bar{k}_{1}(t)+\bar{\varphi}_{w} h_{1} w_{1}(t) T_{1}(t)
$$

where $r_{1} \equiv 1+r^{*}, \bar{\varphi}_{k} \equiv 1-\varphi_{k}$ and $\bar{\varphi}_{w} \equiv 1-\varphi_{w}$. The disposable income is spent on saving $s_{1}(t)$ and consumption $c_{1}(t)$. The budget constraint is given by:

$$
c_{1}(t)+s_{1}(t)=\hat{y}_{1}(t) \cdot(4)
$$

This equation means that the consumers' disposable income is fully spent on consumption and savings. Let $\bar{T}_{j}(t)$ stand for group leisure time at time $t$. The (fixed) available time for work and leisure by $T_{0}$. The time constraint for each group is:

$$
T_{j}(t)+\bar{T}_{j}(t)=T_{0}, \quad j=1,2 .(5)
$$

Substitute (3) and (5) into (4):

$$
c_{1}(t)+s_{1}(t)+\bar{w}_{1}(t) \bar{T}_{1}(t)=\bar{y}_{1}(t) \equiv \bar{\varphi}_{k} r_{1} \bar{k}_{1}(t)+\bar{w}_{1}(t) T_{0},
$$

where $\bar{w}_{1}(t) \equiv \bar{\varphi}_{w} h_{1} w_{1}(t)$.

\section{Officials' Disposable Income and Budget Constraint}

Let $\bar{k}_{2}(t)$ to present the capital wealth owned by the representative official. We assume that the representative official's wage income per unit of qualified work time is paid in proportion to the worker's wage rate as follows: 


$$
\bar{w}_{2}(t)=u_{0} h_{2} w_{1}(t)
$$

where the policy parameter $u_{0}>0$ is determined by the government budget. The official wage rate is proportional to the worker's market wage rate. According to the definitions of the corruption rates, the representative official receives the total income due to corruption as follows:

$$
w_{c}(t) \equiv \frac{\varphi F(t)+r_{1} \varphi_{k} \bar{k}_{1}(t) \bar{N}_{1}+\varphi_{w} h_{1} w_{1}(t) T_{1}(t) \bar{N}_{1}}{\bar{N}_{2}} .
$$

The representative official's disposable income $\hat{y}_{2}$ is given by:

$$
\hat{y}_{2}(t) \equiv r_{1} \bar{k}_{2}(t)+\bar{w}_{2}(t) T_{2}(t)+w_{c}(t)
$$

The disposable income is spent on saving $s_{2}(t)$ and consumption $c_{2}(t)$. The budget constraint implies:

$$
c_{2}(t)+s_{2}(t)=\hat{y}_{2}(t) \cdot(10)
$$

Substitute (9) and (5) into (10):

$$
c_{2}(t)+s_{2}(t)+\bar{w}_{2}(t) \bar{T}_{2}(t)=\bar{y}_{2}(t) \equiv r_{1} \bar{k}_{2}(t)+\bar{w}_{2}(t) T_{0}+w_{c}(t) \text {. }
$$

\section{The Utility Functions and Optimal Decisions}

Group $j$ 's representative household chooses three variables, $c_{j}(t), s_{j}(t)$ and $\bar{T}_{j}(t)$ subject to the budget constraint. Group $j$ 's utility level $U_{j}(t)$ is related to the three variables as follows:

$$
U_{j}(t)=u_{j}(G(t), t) \bar{T}_{j}^{\sigma_{0 j}}(t) c_{j}^{\xi_{0 j}}(t) s_{j}^{\lambda_{0 j}}(t), \sigma_{0 j}, \xi_{0 j}, \lambda_{0 j}>0,
$$

where $u_{j}$ is a time-dependent variable, $\sigma_{0 j}, \xi_{0 j}$ and $\lambda_{0 j}$ are respectively the worker's/ official's propensity to stay at home, the propensities to consume good, and to hold wealth. Maximizing $U_{j}$ subject to budget constraint (6)/(11) yields:

$$
\bar{w}_{j}(t) \bar{T}_{j}(t)=\sigma_{j} \bar{y}_{j}(t), \quad c_{j}(t)=\xi_{j} \bar{y}_{j}(t), \quad s_{j}(t)=\lambda_{j} \bar{y}_{j}(t)
$$

where

$$
\rho_{j} \equiv \frac{1}{\sigma_{0 j}+\xi_{0 j}+\lambda_{0 j}}, \quad \sigma_{j} \equiv \rho_{j} \sigma_{0 j}, \quad \xi_{j} \equiv \rho_{j} \xi_{0 j}, \quad \lambda_{j} \equiv \rho_{j} \lambda_{0 j} .
$$

\section{The Wealth Accumulation}

According to the definitions of $s_{j}(t)$ and $\bar{k}_{j}$ group $j$ 's change in the household's wealth implies:

$$
\dot{\bar{k}}_{j}(t)=s_{j}(t)-\bar{k}_{j}(t) \cdot(13)
$$


The equations mean that the change in wealth is equal to saving minus dissaving.

\section{The Public Sector}

The government spends all its tax income on the public sector to provide public services. The public sector has the total income $\tau(t) F(t)$. We assume that the service that the public provides is dependent only on the officials' labor input $N_{2}(t)$. The public sector's production function is taken on the following form:

$$
G(t)=A_{p} N_{2}^{\gamma}(t), A_{p}, \gamma>0 .(14)
$$

The public sector's expenditure is $\bar{w}_{2}(t) T_{2}(t) \bar{N}_{2}$. The government budget implies:

$$
\bar{w}_{2}(t) T_{2}(t) \bar{N}_{2}=\tau(t) F(t)
$$

This study neglects possible corruption of the officials on governance and government expenditures. The interaction between corruption and the efficiency of public spending is modelled, for instance, by Dzhumashev (2014).

\section{Wealth Being Owned by the Households}

The sum of the wealth owned by the two groups is equal to the national capital

$$
\bar{k}_{1}(t) \bar{N}_{1}+\bar{k}_{2}(t) \bar{N}_{2}=\bar{K}(t) \text {. (16) }
$$

We built the model. The dynamic general equilibrium model describes the interdependence between wealth accumulation of the workers and officials, public goods supply, income and wealth distribution, endogenous labor supply, and economic structure with different ways of corruption. The rest of the paper deals with properties of the model.

\section{The Behavior of the Model}

This section examines properties of the nonlinear dynamic model. The following lemma shows that the motion of the economic system can be described by two differential equations. The following lemma is checked in the Appendix.

\section{Lemma}

Let $z(t) \equiv\left(r^{*}+\delta_{k}\right) / w_{1}(t)$. The dynamics of the economic system is governed by the following two differential equations:

$$
\begin{aligned}
& \dot{z}(t)=\tilde{f}_{1}(z(t), G(t)), \\
& \dot{G}(t)=\tilde{f}_{2}(z(t), G(t)),
\end{aligned}
$$


where are functions of and defined in the appendix. The values of all the other variables are uniquely determined as functions of and at any point in time by the following procedure: by $(\mathrm{A} 3) \rightarrow \bar{k}_{1}(t)$ and $\bar{k}_{2}(t)$ by $(\mathrm{A} 14) \rightarrow w_{1}(t)$ by $(\mathrm{A} 1) \rightarrow \bar{w}_{2}(t)$ by $(7) \rightarrow N_{1}(t)$ by (A6) $\rightarrow$ $w_{c}(t)$ by $(\mathrm{A} 7) \rightarrow N_{2}(t)$ by $(\mathrm{A} 11) \rightarrow K(t)$ by $(\mathrm{A} 1) \rightarrow \bar{y}_{j}(t)$ by $(\mathrm{A} 8) \rightarrow F(t)$ by $(\mathrm{A} 3) \rightarrow c_{j}(t)$, $s_{j}(t)$ and $\bar{T}_{j}(t)$ by $(12)$.

As the expressions of the Lemma are tedious, difficult to interpret the analytical results. We illustrate dynamic properties of the economic system by simulation. The parameter values are specified as follows:

$$
\begin{aligned}
& r^{*}=0.07, \bar{N}_{1}=100, \bar{N}_{2}=10, T_{0}=24, h_{1}=2.5, h_{2}=2.5, \alpha_{i}=0.3, A=1.2, A_{p}=0.7, \\
& \xi_{01}=0.15, \lambda_{01}=0.4, \sigma_{01}=0.3, \xi_{02}=0.15, \lambda_{02}=0.5, \sigma_{02}=0.25, \theta=0.1, \gamma=0.3, \\
& u_{0}=1.5, \varphi=0.03, \varphi_{k}=0.05, \varphi_{w}=0.05, \delta_{k}=0.05 \text {. }(18)
\end{aligned}
$$

The rate of interest is 7 percent. The ratio between the number of the workers and the number of the officials is 10:1. The worker and official have the same level of human capital. The following calculation shows that the representative worker's relative propensity to save is lower than the official's relative propensity to save:

$$
\lambda_{1}=\frac{0.4}{0.4+0.3+0.15}=\frac{8}{17}<\lambda_{2}=\frac{0.5}{0.5+0.15+0.25}=\frac{5}{9} .
$$

Intuitively this implies the possibility that corruption benefits economic growth since corruption may shift wealth from the group with the lower propensity to save to the group with higher propensity to save. The two groups have the same level of human capital. The ratio of the wages between the official and worker is fixed by the government at 1.5. The initial conditions are specified as follows:

$$
z(0)=0.091, G(0)=2.8 \text {. }
$$

The changes of the variables over time are plotted in Figure 1. The worker and official supply more labor. The national product and wealth rise. The income due to corruption fall. The wage rates and wage incomes of the worker and the official are enhanced. The economy employs more capital and produces more output. 
Figure 1. The Motion of the Economic System
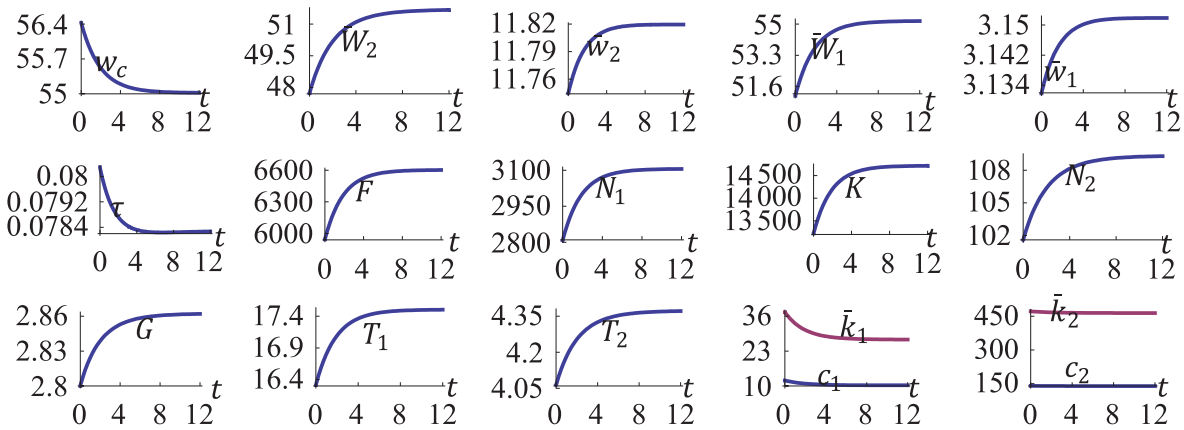

It is straightforward to confirm the following equilibrium values of the variables:

$$
\begin{aligned}
& \tau=0.078, w_{c}=55.02, w_{1}=1.33, \bar{w}_{2}=11.8, \bar{W}_{1}=55.2, \bar{W}_{2}=51.7, N_{1}=3106, \\
& N_{2}=109.3, \bar{K}_{1}=2730, \bar{K}_{2}=4640, F=6603.7, G=2.86, \bar{k}_{1}=27.3, \bar{k}_{2}=464, \\
& T_{1}=17.5, \bar{T}_{1}=6.5, T_{2}=4.4, \bar{T}_{2}=19.6, c_{1}=10.2, c_{2}=139.2,
\end{aligned}
$$

where $\bar{W}_{j}=\bar{w}_{j} T_{j}$. The eigenvalues are

$-0.532,-0.346$.

The equilibrium point is stable. This result enables us to effectively conduct comparative dynamic analysis.

\section{Comparative Dynamic Analysis}

We plotted the motion of the economic system in the previous section. We are now concerned with how a change in any parameter alters the motion of the system. As the system is stable, we can effectively conduct comparative dynamic analysis. We introduce the variable, $\bar{\Delta} x(t)$, to stand for the change rate of the variable, $x(t)$, in percentage due to changes in the parameter value.

\section{The Corruption Rate on the Output Level Being Increased}

We first examine how the following rise in the corruption rate on the output level affects the motion of the economic system over time: $\varphi: 0.03 \Rightarrow 0.04$ where " $\Rightarrow$ " stands for "being changed to". The output rises initially and falls in the long term. As the corruption rate is increased, the tax rate $\tau$ falls. The official's wage rate per unit time $\bar{w}_{2}$ and the official's wage income $\bar{W}_{2}$ are reduced. The corrupt income $w_{c}$ is increased. The worker's wage rate per unit time $\bar{w}_{1}$ falls. The worker's wage income $\bar{W}_{1}$ rises initially and is reduced in the long term. The official spends longer hours on leisure and less hours on work. The public service supply is 
reduced. The official consumes more. The official owns less wealth initially and more in the long term. The representative worker consumes less. The worker's consumption level and wealth are reduced in the short term but are affected slightly in the long term. The worker spends less time on leisure in the short term but almost the same hours in the long term. The national output falls initially but falls slightly in the long term. The national labor supply and capital employed by the economy are increased in the short term but is affected slightly.

Figure 2. The Corruption Rate on the Output Level Being Increased
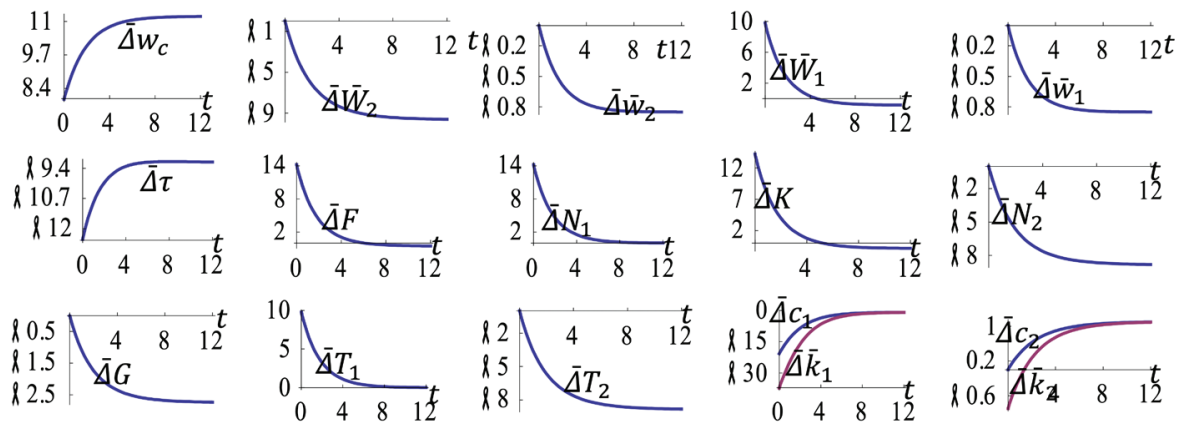

\section{The Corruption Rate on the Wage Income Being Increased}

We now allow the corruption rate on the wage income to be increased as follows: $\varphi_{w}: 0.05 \Rightarrow 0.06$. The official's income from corruption is increased. The tax rate falls. The wage rates and wage incomes of the worker and official are reduced. The capital employed by the economy falls in the short term and rises in the long term. The national output level and labor supply are reduced initially and affected slightly in the long term. The worker spends less hours on working initially and changes slightly the working hours in the long term. The official works less hours. The worker's consumption level and wealth rise in the short term and fall in the long term. The national official labor supply falls and the national public service falls.

Figure 3. The Corruption Rate on the Wage Income Being Increased
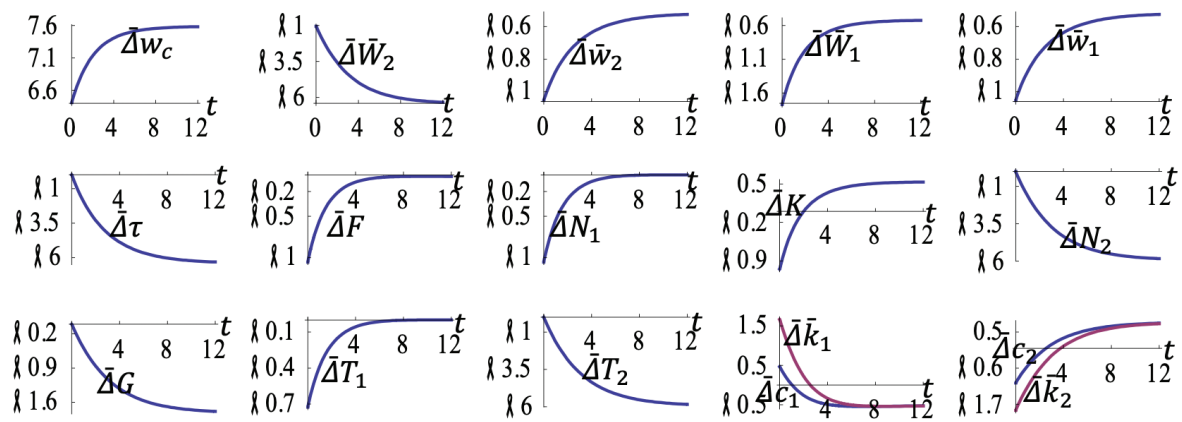


\section{The Corruption Rate on the Capital Income Being Increased}

The corruption rate on the capital income is supposed to rise as follows: $\varphi_{k}: 0.05 \Rightarrow 0.06$ The income from corruption is increased. The official wage income rises and the official's wage rate is increased. The worker's wage rate and wage income are increased. The official consumes less initially and more in the long term. The official owns more wealth. The worker's consumption level and wealth are reduced. The worker works long hours and the official works less hours. The national labor input is increased and the national public labor input is reduced. The public service falls. The capital employed by the economy and national output are increased. The tax rate falls.

Figure 4. The Corruption Rate on the Capital Income Being Increased
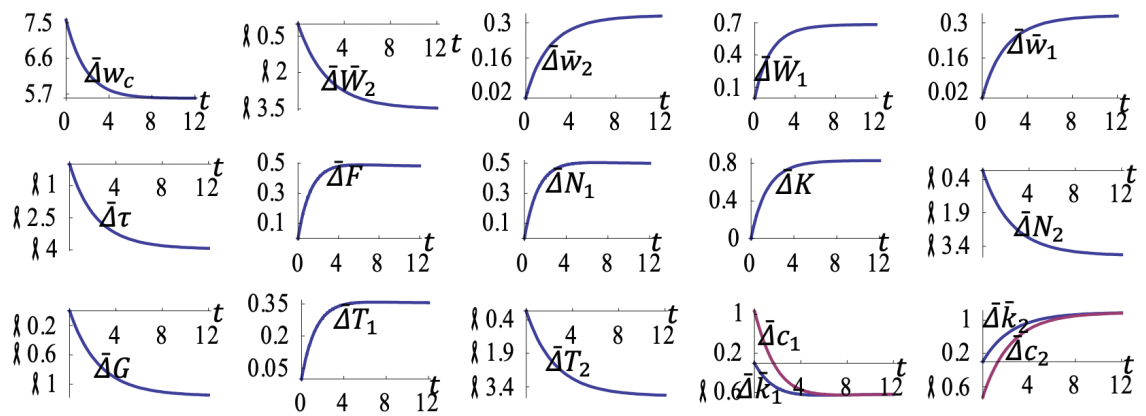

\section{The Worker's Human Capital Being Enhanced}

We now allow the worker's human capital to be enhanced as follows: $h_{1}: 2.5 \Rightarrow 2.6$. The tax rate is reduced. The public labor input and production sector's labor input are increased. The national output and public sector's output are augmented. The worker and official work longer hours. The worker's and official's consumption levels and wealth are augmented. The tax rate falls. The official's and worker's consumption levels and wealth are augmented. The income due to corruption is increased.

Figure 5. The Worker's Human Capital Being Enhanced
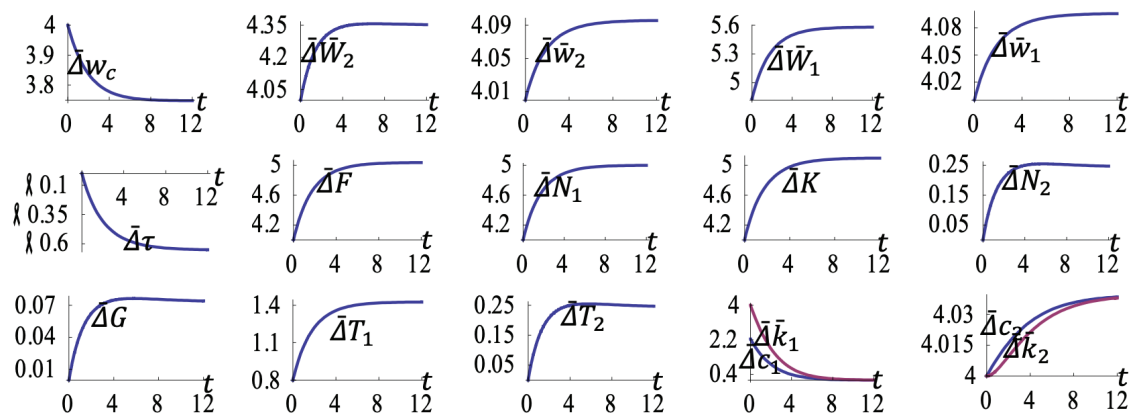


\section{The Official's Human Capital Being Augmented}

We now allow the official's human capital to be augmented as follows: $h_{2}: 2.5 \Rightarrow 2.6$. The national public service is increased over time. The rise of the national output expansion is mainly caused by the rise in the public service. The worker and official work longer hours. The worker's consumption level and wealth are reduced. The official's consumption level and wealth are augmented. The tax rate is increased. The official's wage rate per unit time and wage income are enhanced. The corrupt income $w_{c}$ falls. The worker's wage rate per unit time and wage income fall.

Figure 6. The Official's Human Capital Being Augmented
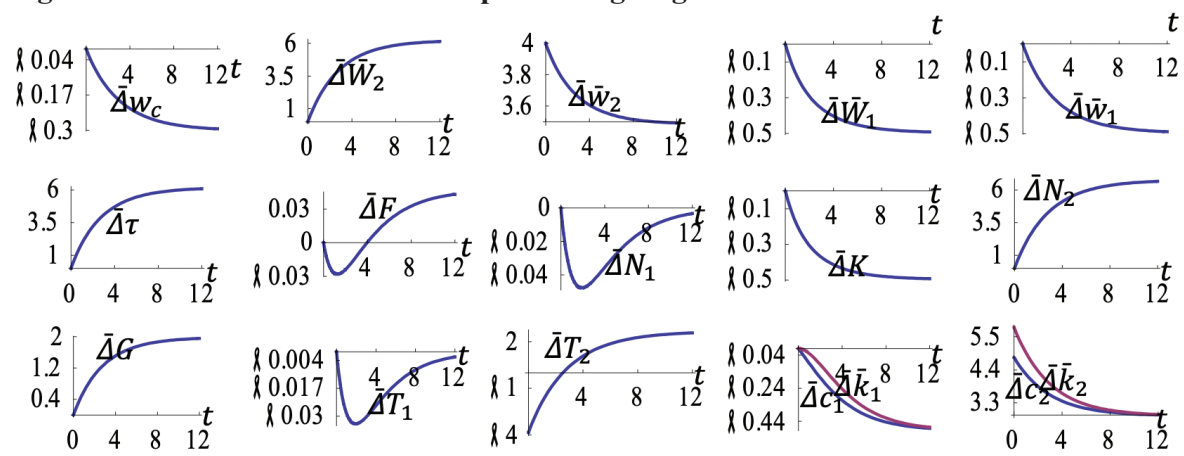

\section{The Number of Officials Being Increased the Number of the Workers Being Reduced}

This study assumes the total population fixed. The share of officials in the population may vary. We consider an exogenous change in the share. We now allow the following shift of the labor force structure

$$
\bar{N}_{1}: 100 \Rightarrow 99, \bar{N}_{2}: 10 \Rightarrow 11 \text {. }
$$

The tax rate is enhanced and the corrupt income per official falls. The official's wage rate falls. The official's wage income falls in the short term and rises in the long term. The official consumes more and owns more wealth in the short term and consumes less and owns less wealth in the long term. The officials supply more national service labor input. The national service rises. The workers supply more labor input. The economy employs less capital and produces less. It should be noted that in the literature of corruption and growth the relation between government size and economic growth may be opposite, depending on the analytical framework or economies under consideration. One argument is that a rise in the government size may produce more opportunities for corruption (e.g., Goel and Nelson, 1998; Rose-Ackerman, 1999; Alesina and Angeletos, 2005). The other argument is that an enlarged government sector may strengthen control of corruption and thus encourage 
economic growth (Billger and Goel, 2009). In our analytical framework the expansion of the government harms economic growth.

Figure 7. The Number of Officials Being Increased
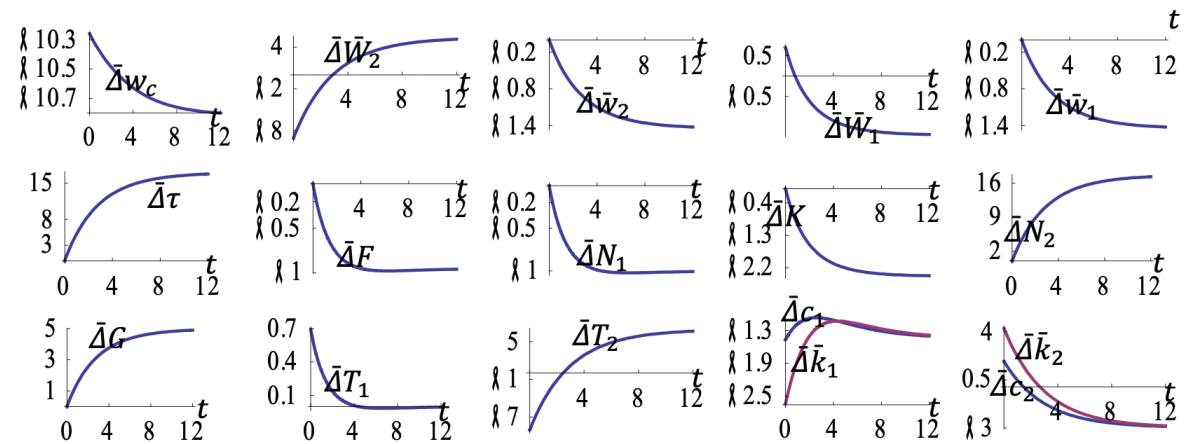

\section{The Worker's Propensity to Use Leisure Time Being Enhanced}

We now allow the worker's propensity to stay at home to be enhanced as follows: $\sigma_{01}: 0.3 \Rightarrow 0.31$. The worker's work time leisure time falls initially and rises in the long term. The national labor input of the production sector falls, and the economy employs less capital. The national output falls. The tax rate is enhanced. The official works longer hours. The public labor input is augmented. The public sector's output is augmented. The worker's consumption levels, and wealth are lowered. The worker's consumption levels, and wealth are lowered in the long term. The income due to corruption is reduced.

Figure 8. The Worker's Propensity to Use Leisure Time Being Enhanced
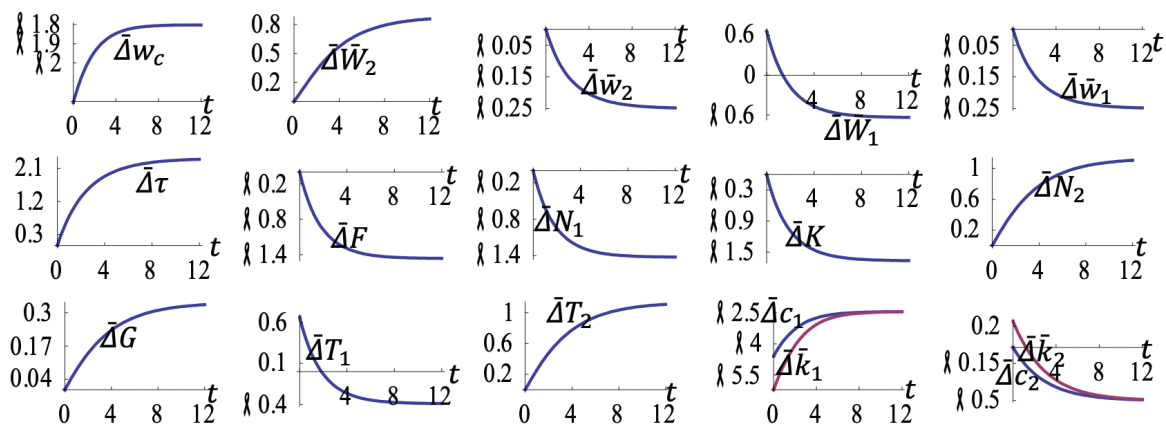


\section{The Official's Propensity to Stay at Home Being Enhanced}

We now allow the official's propensity to stay at home to be enhanced as follows: $\sigma_{02}: 0.25 \Rightarrow 0.27$. The worker's work time leisure time falls initially and changes slightly in the long term. The official stay at home long hours. The public labor input is reduced. The public sector's output is lowered. The national labor input of the production sector rises initially and changes slightly in the long term. The economy employs more capital. The national output rises slightly initially and falls in the long term. The tax rate is lowered. The worker's consumption level and wealth are enhanced. The official's consumption level and wealth are lowered. The income due to corruption is augmented.

Figure 9. The Official's Propensity to Stay at Home Being Enhanced
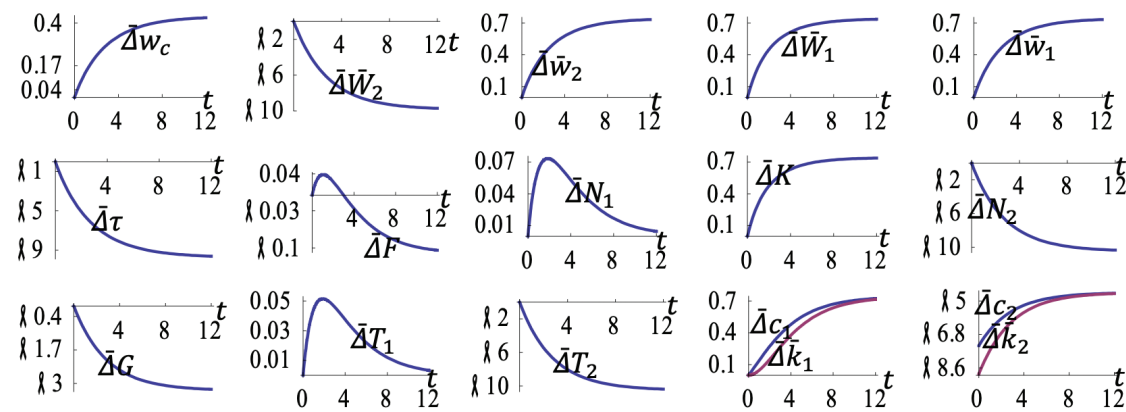

\section{The Ratio Between the Two Groups' Wages Being Enhanced}

We now allow the ratio of the wages between the official and worker to be enhanced as follows: $u_{0}: 1.5 \Rightarrow 1.6$. The official is relatively paid more than the worker. The income due to corruption is reduced. The worker's work time rises initially and changes slightly in the long term. The worker's total wage income rises in the short term and falls in the long term. The official's wage rate and wage income are enhanced. The worker works longer hours in the short term and woks almost the same hours in the long term.

Figure 10. The Ratio Between the Two Groups' Wages Being Enhanced
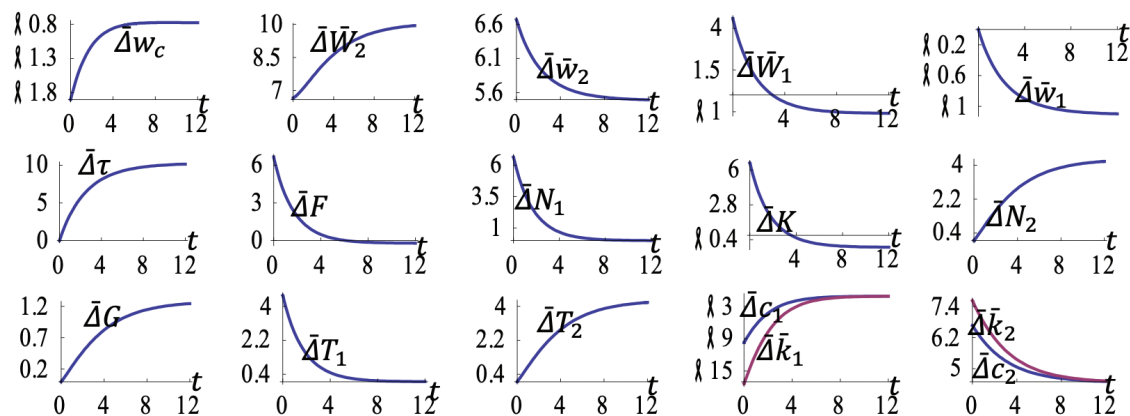


\section{Concluding Remarks}

This study constructed a dynamic general equilibrium model of endogenous wealth and corruption. The small-open economy consists of one (private) production sector and one public sector. The population is classified into workers and officials. The public service sector employs officials as input and receives the government's financial support. The government taxes the production sector. The tax rate is endogenously determined. The public sector's output affects the private sector's productivity and the people's welfare. The production sector employs the workers' labor inputs and capital. Capital is traded in global markets. Officials are corrupt in the sense that they take bribes from the private sector and households. The corruption is measured by the corruption rates on the output level of the private sector, the wealth interest returns of the workers, and the wage income of the workers. We simulated the model and identified the existence of a unique stable equilibrium. We also plotted the transitory and long-run effects of changes in some parameters. Our model can be generalized and extended in different ways. For instance, except the corruption channels modelled in this study, there are other possible channels of corruption. Corruption channels are closely related to institutional structures. It is important to allow both workers and officials to be heterogeneous in terms of morality, position, and human capital.

Peer-review: Externally peer-reviewed.

Conflict of Interest: The author has no conflict of interest to declare.

Grant Support: The author declared that this study has received no financial support.

Acknowledgements: I would like to thank the anonymous referee and Assistant Editor Betul Mutlugun for valuable comments and suggestions. The usual caveat applies.

\section{References}

Acemoglu, D., \& Verdier, T. (1998). Property rights, corruption and the allocation of talent: A general equilibrium approach. Economic Journal, 108(450), 1381-1403.

Aghion, P., Akcigit, U., Cage, J., \& Kerr, W. R. (2016). Taxation, corruption, and growth. European Economic Review, 86(1), 24-51.

Alesina, A., \& Angeletos, G. M. (2005). Corruption, inequality, and fairness. Journal of Monetary Economics, $52(7), 1227-44$.

Baier, S. L., \& Glomm, G. (2001). Long-run growth and welfare effects of public policies with distortionary taxation. Journal of Economic Dynamics and Control, 25(12), 2007-42.

Barro, R. J. (1990). Government spending in a simple model of endogenous growth. Journal of Political Economy, 98(S5), 103-25.

Barro, R. J. \& X. Sala-i-Martin (1995). Economic growth. New York: McGraw-Hill, Inc.

Becker, G. (1968). Crime and punishment: An economic approach. Journal of Political Economy, 76(2), $169-217$.

Benigno, G., \& Benigno, P. (2003). Price stability in open economies. Review of Economic Studies, 70(4), $743-64$. 
Billger, S. M., \& Goel, R. K. (2009). Do existing corruption levels matter in controlling corruption? Cross-country quantile regression estimates. Journal of Development Economics, 90(2), 299-305.

Burmeister, E., \& Dobell, A. R. (1970). Mathematical theories of economic growth. London: Collier Macmillan Publishers.

Chea, C. C. (2015). Empirical studies: Corruption and economic growth. American Journal of Economics, 5(2), $183-88$

Chen, S. H., \& Guo, J. T. (2014). Progressive taxation and macroeconomic (1n)stability with utility-generating government spending. Journal of Macroeconomics, 42(C), 174-83.

D’Agostino, G., Dunne, P., \& Pieroni, L. (2016). Government spending, corruption and economic growth. World Development, 84(C), 190-205.

De Vaal, A., \& Ebben, W. (2011). Institutions and the relation between corruption and economic growth. Review of Development Economics, 15(1), 108-23.

Del Monte, A., \& Papagni, E. (2001). Public expenditure, corruption, and economic growth: The case of Italy. European Journal of Political Economy, 17(1), 1-16.

Dzhumashev, R. (2014). Corruption and growth: The role of governance, public spending, and economic development. Economic Modelling, 37(C), 201-15.

Ehrlich, I., \& Lui, F. T. (1999). Bureaucratic corruption and endogenous economic growth. Journal of Political Economy, 107(6), S270-S293.

Gali, J., \& Monacelli, T. (2005). Monetary policy and exchange rate volatility in a small open economy. Review of Economic Studies, 72(3), 707-34.

Glaeser, E., \& Saks, R. (2006). Corruption in America. Journal of Public Economics, 90(6-7), 1053-72.

Glomm, G., \& Ravikumar, B. (1997). Productive government expenditures and long-run growth. Journal of Economic Dynamics and Control, 21(1), 183-204.

Goel, R. K., \& Nelson, M. A. (1998). Corruption and government size: A disaggregated analysis. Public Choice, 97(October), 107-20.

Gyimah-Brempong, K. (2002). Corruption, economic growth and income inequality in Africa. Economics and Government, 3(3), 183-209.

Hu, Y., Ohdoi, R. \& Shimomura, K. (2008). Indeterminacy in a two-sector endogenous growth model with productive government spending. Journal of Macroeconomics, 30(3), 1104-23.

Huntington, S. P. (19689 Political order in changing societies. New Haven: Yale University Press.

Ilzetzkia, E., Mendozab, E. G., \& Veghc, G. A. (2013). How big (small?) are fiscal multipliers? Journal of Monetary Economics, 60(2), 239-54.

Kamiguchi, A., \& Tamai, T. (2011). Can productive government spending be a source of equilibrium indeterminacy? Economic Modelling, 28(3), 1335-40.

Kollmann, R. (2001). The exchange rate in a dynamic-optimizing business cycle model with nominal rigidities: A quantitative investigation. Journal of International Economics, 55(2), 243-62.

Kollmann, R. (2002). Monetary policy rules in the open economy: Effects on welfare and business cycles. Journal of Monetary Economics, 49(5), 899-1015.

Lane, P. R. (2001). The new open economy macroeconomics: A survey. Journal of International Economics, 54(2), 235-66.

Leff, N. H. (1964). Economic development through bureaucratic corruption. The American Behavioral Scientist, $8(3), 8-14$. 
Lin, S. L., \& Zhang, W. (2009). The effect of corruption on capital accumulation. Journal of Economics, 97(1), 67-93.

Mauro, P. (1995). Corruption and growth. Quarterly Journal of Economics, 110(3), 681-712.

Mauro, P. (1998). Corruption and the composition of government expenditure. Journal of Public Economics, 69(2), 263-79.

Myrdal, G. (1968). Asian drama. New York: Random House.

Obstfeld, M., \& Rogoff, K. (1996). Foundations of international macroeconomics. Mass., Cambridge: MIT Press.

Palivos, T., Yip, C. Y., \& Zhang, J. (2003). Transitional dynamics and indeterminacy of equilibria in an endogenous growth model with a public input. Review of Development Economics, 7(1), 86-98.

Rivera-Batiz, F.L. (2001). International financial liberalization, corruption, and economic growth. Review of International Economics, 9(4), 727-737.

Rose-Ackerman, S. (1999). Corruption and government: Causes, consequences, and reform. Cambridge: Cambridge University Press.

Shi, S.Y. \& Temzelides, T. (2004). A model of bureaucracy and corruption. International Economic Review, 45(3), 873-906.

Swaleheen, M., \& Stansel, D. (2007). Economic freedom, corruption and growth. Cato Journal, 27(3), 343-58.

Teles, V.K. (2007). Institutional quality and endogenous economic growth. Journal of Economic Studies, 34(1), $29-41$.

Turnovsky, S.J. (2000). Fiscal policy, elastic labor supply, and endogenous growth. Journal of Monetary Economics, 45(1), 185-210.

Turnovsky, S.J. (2004). The transitional dynamics of fiscal policy: Long-run capital accumulation and growth. Journal of Money, Credit, and Banking, 36(5), 883-910.

Uya, T., Yi, K. M., \& Zhang, J. (2013). Structural change in an open economy. Journal of Monetary Economics, 60(September), 667-82.

Zhang, W. B. (1993). Woman's labor participation and economic growth - Creativity, knowledge utilization and family preference. Economics Letters, 42(1), 105-110.

Zhang, W. B. (2009). Monetary growth theory: Money, interest, prices, capital, knowledge, and economic structure over time and space. London: Routledge.

Zhang, W. B. (2010). Economic growth with endogenous labor supply and public good. Global Review of Business and Economic Research, 8 (2), 253-72.

Zhang, W. B. (2020). The general economic theory: An integrative approach. Switzerland: Springer International Publishing. 


\section{Appendix: Proving the Lemma}

From (2) we have:

$z \equiv \frac{r_{0}}{w_{1}}=\frac{N_{1}}{\bar{\beta}_{i} K}$

where $\bar{\beta}_{i} \equiv \beta_{i} / \alpha_{i}$. From (A1), (1) and (2), we have:

$r_{0}=A_{r} \bar{\varphi} G^{\theta} Z^{\beta_{i}}$,

where $A_{r}=\alpha_{i} A \bar{\beta}_{i}^{\beta_{i}}$. Equation (A2) and $\bar{\varphi} \equiv 1-\varphi-\tau$ imply:

$\tau=1-\varphi-\frac{r_{0}}{A_{r} G^{\theta} Z^{\beta_{i}}}$

Equations (1) and (2) imply:

$F=N_{1} f, \quad(\mathrm{~A} 4)$

where $f \equiv A G^{\theta} / \bar{\beta}_{i}^{\alpha_{i}} z^{\alpha_{i}}$. From (12) we have:

$\bar{T}_{1}=\sigma_{1} T_{0}+\frac{\sigma_{1} \bar{\varphi}_{k} r_{1} \bar{k}_{1}}{\bar{w}_{1}}$

From the definition of $N_{1}$, (A5) and (5) we get:

$N_{1}=n_{0}-n \bar{k}_{1}, \quad(\mathrm{~A} 6)$

where

$n_{0} \equiv\left(1-\sigma_{1}\right) h_{1} \bar{N}_{1} T_{0}, \quad n \equiv \frac{\sigma_{1} h_{1} r_{1} \bar{N}_{1} \bar{\varphi}_{k}}{\bar{w}_{1}}$.

From (8) and (A4) we have

$w_{c}=q_{z} N_{1}+q_{k} \bar{k}_{1}+q_{0}, \quad$ (A7)

where we also use (6) and (12) and:

$q_{z} \equiv \frac{\varphi f}{\bar{N}_{2}}, \quad \varphi_{0} \equiv \frac{\varphi_{w} \sigma_{1} \bar{N}_{1}}{\bar{\varphi}_{w}}, \quad q_{k} \equiv \frac{r_{1} \varphi_{k} \bar{N}_{1}-r_{1} \varphi_{0} \bar{\varphi}_{k}}{\bar{N}_{2}}, \quad q_{0} \equiv \frac{\varphi_{w} h_{1} w_{1} T_{0} \bar{N}_{1}-\varphi_{0} \bar{w}_{1} T_{0}}{\bar{N}_{2}}$.

From (6), (11) and (A6) we have 
$\bar{y}_{1}=\bar{\varphi}_{k} r_{1} \bar{k}_{1}+\bar{\varphi}_{w} w_{1} T_{0}$

$\bar{y}_{2}=r_{1} \bar{k}_{2}+\bar{w}_{2} T_{0}+q_{z} N_{1}+q_{k} \bar{k}_{1}+q_{0}$. (A8)

From (12) and the time constraint we have

$T_{2}=T_{0}-\frac{\sigma_{2} \bar{y}_{2}}{\bar{w}_{2}}$

Insert (A8) in (A9):

$T_{2}=\left(1-\sigma_{2}\right) T_{0}-\sigma_{2}\left(\frac{r_{1} \bar{k}_{2}+q_{z} N_{1}+q_{k} \bar{k}_{1}+q_{0}}{\bar{w}_{2}}\right)$.

Insert (A6) and (A10) in $N_{2}=h_{2} \bar{N}_{2} T_{2}$ :

$N_{2}=\tilde{n}-\bar{n} \bar{k}_{1}-\frac{r_{1} h_{2} \bar{N}_{2} \sigma_{2} \bar{k}_{2}}{\bar{w}_{2}}$,

where

$\tilde{n}=\sigma_{2} h_{2} \bar{N}_{2}\left(\left(\frac{1}{\sigma_{2}}-1\right) T_{0}-\frac{q_{z} n_{0}+q_{0}}{\bar{w}_{2}}\right), \quad \bar{n}=\sigma_{2} h_{2} \bar{N}_{2}\left(\frac{q_{k}-n q_{z}}{\bar{w}_{2}}\right)$.

Insert (A11) in (14):

$\bar{n} \bar{k}_{1}+\frac{r_{1} h_{2} \bar{N}_{2} \sigma_{2} \bar{k}_{2}}{\bar{w}_{2}}=\tilde{n}-\left(\frac{G}{A_{p}}\right)^{\frac{1}{\gamma}}$.

Insert (A4) in (15):

$\bar{w}_{2} T_{2} \bar{N}_{2}=\tau N_{1} f .(\mathrm{A} 13)$

Insert (A6) and (A10) in (A13):

$\left(\frac{n \tau f}{\sigma_{2} \bar{N}_{2}}+q_{z} n-q_{k}\right) \bar{k}_{1}-r_{1} \bar{k}_{2}=q_{z} n_{0}+q_{0}+\frac{\tau f n_{0}}{\sigma_{2} \bar{N}_{2}}-\left(\frac{1}{\sigma_{2}}-1\right) T_{0} \bar{w}_{2}$.

Solving linear equations (A12) and (A14) with $\bar{k}_{1}$ and $\bar{k}_{2}$ as variables, we have:

$\bar{k}_{j}=f_{j}(z, G) \cdot(\mathrm{A} 15)$

We don't provide the expressions of the solution as it is straightforward and tedious. We show now that all the variables can be expressed as functions of $z$ and $G$ as follows: $\tau$ by $(\mathrm{A} 3) \rightarrow \bar{k}_{1}(t)$ and $\bar{k}_{2}(t)$ by $(\mathrm{A} 14) \rightarrow w_{1}$ by (A1) $\rightarrow \bar{w}_{2}$ by (7) $\rightarrow N_{1}$ by (A6) $\rightarrow w_{c}$ by (A7) $\rightarrow N_{2}$ by (A11) $\rightarrow K$ by (A1) $\rightarrow \bar{y}_{j}$ by (A8) $\rightarrow F$ by (A3) $\rightarrow c_{j}$, $s_{j}$, and $\bar{T}_{j}$ by (12). From this procedure and (13), we have: 
$\dot{\bar{k}}_{j}=\bar{f}_{j}(z, G) \equiv s_{j}-\bar{k}_{j} .(\mathrm{A} 16)$

Take derivatives of (A15) with respect to $t$

$\dot{\bar{k}}_{j}=\frac{\partial f_{j}}{\partial z} \dot{z}+\frac{\partial f_{j}}{\partial G} \dot{G}, j=1,2 .(\mathrm{A} 17)$

Insert (A16) in (A17):

$\frac{\partial f_{j}}{\partial z} \dot{z}+\frac{\partial f_{j}}{\partial G} \dot{G}=\bar{f}_{j}, \quad j=1,2$. (A18)

Solve (A23):

$\dot{z}=\tilde{f}_{1}(z, G)$,

$\dot{G}=\tilde{f}_{2}(z, G)$. (A19)

We thus proved the Lemma. 